\title{
Introducing cattle grazing to a noxious weed-dominated rangeland shifts plant communities
}

by Josh S. Davy, Leslie M. Roche, Alexis V. Robertson, Dennis E. Nay and Kenneth W. Tate

Invasive weed species in California's rangelands can reduce herbaceous diversity, forage quality and wildlife habitat. Small-scale studies (5 acres or fewer) have shown reductions of medusahead and yellow starthistle using prescribed grazing on rangelands, but little is published on the effects of pasture-scale (greater than 80 acres) prescribed grazing on weed control and plant community responses. We report the results of a 6-year collaborative study of manager-applied prescribed grazing implemented on rangeland that had not been grazed for 4 years. Grazing reduced medusahead but did not alter yellow starthistle cover. Medusahead reductions were only seen in years that did not have significant late spring rainfall, suggesting that it is able to recover from heavy grazing if soil moisture is present. Later season grazing appears to have the potential to suppress medusahead in all years. In practice, however, such grazing is constrained by livestock drinking water availability and forage quality, which were limited even in years with late spring rainfall. Thus, we expect that grazing treatments under real-world constraints would reduce medusahead only in years with little late spring rainfall. After 10 years of grazing exclusion, the ungrazed plant communities began to shift, replacing medusahead with species that have little value, such as ripgut and red brome.

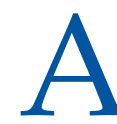
cross California, annual rangelands cover approximately 16 million acres and are among the most species-rich ecosystems in the state, supporting thousands of plant and animal species (Allen-Diaz et al. 2007; Barrett
1980; Garrison and Standiford 1996).

California's modern-day rangelands are largely dominated by nonnative annuals, which some believe replaced previously diverse native forb and grass communities (Bartolome 1987; Schiffman 2007).
These naturalized annuals now provide a majority of the state's livestock forage base. Currently, several noxious weed species are driving another transformation of California's rangelands and pose a continued and growing threat to rangeland ecosystem functions and services (D'Antonio et al. 2007; DiTomaso 2000; Kyser et al. 2007; Young 1992).

The spread of invasive weeds changes plant community composition and can lead to shifts in soil moisture and nutrient availability as well as the suppression of both native plants and other desirable and more palatable nonnatives, thereby reducing herbaceous diversity, wildlife habitat, forage quality and agricultural productivity (DiTomaso 2000; Eviner et al. 2010; George 1992). Across California's annual rangelands, noxious weeds have been estimated to reduce livestock carrying capacity by as much as $50 \%$ to $80 \%$ (DiTomaso 2000; George 1992; Hironaka 1961; Major et al. 1960).

Online: http://californiaagriculture.ucanr.edu/ landingpage.cfm?article=ca.v069n04p230\&fulltext=yes doi: 10.3733/ca.v069n04p230
Cattle in a prescribed grazing paddock in the spring. Prescribed grazing reduced medusahead cover in years that did not have significant late spring rainfall.

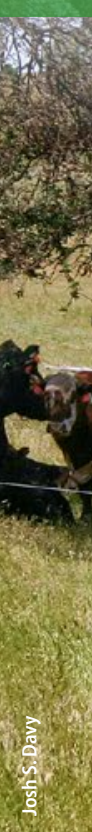




\section{Medusahead and yellow starthistle}

Two of the most prominent invasive species of concern are medusahead (Elymus caput-medusae L., synonym: Taeniatherum caput-medusae L. Nevski) and yellow starthistle (Centaurea solstitialis L.). Together, these rapidly expanding species cover more than 15 million acres throughout California (DiTomaso and Healy 2007; DiTomaso et al. 2008; Pitcairn et al. 1998; Young 1992).

The phenological development of medusahead and yellow starthistle is in part what makes these invaders so successful. Medusahead, and particularly yellow starthistle, mature late in the annual growing season (November to May). These species germinate after the first fall rains, with smaller germination events sometimes occurring later in the wet season (Benefield et al. 2001). Although germination timing is similar to that of the surrounding grassland community, medusahead does not produce seed heads until late April or May, after most naturalized annuals have completed their life cycle (Dahl and Tisdale 1975; DiTomaso et al. 2008; Young et al. 1970). Yellow starthistle commonly produces seed heads in May and June; it begins flowering in June and can continue beyond October (DiTomaso et al. 2000; DiTomaso et al. 2008). In fact, many of yellow starthistle's developmental stages (seedling, vegetative, flowering, seed formation and maturation) generally extend well into the summer dormant period distinctive to Mediterranean climates (Maddox 1981). The later development periods enable medusahead and yellow starthistle to take advantage of late spring and early summer rains when they occur. When late-season moisture is present, medusahead and yellow starthistle will continue to grow after potential competitors have stopped, allowing them to dominate and dramatically alter the vegetation structure (DiTomaso et al. 2000; Kyser et al. 2007; Young 1992).

\section{Managing weeds with grazing}

Prescribed livestock grazing is commonly proposed as a low-cost, if not profitable, option to manage weedy species on rangelands. Prescribed grazing is the controlled implementation of the timing, frequency and intensity of grazing to achieve specific goal(s), such as weed control. Small-scale grazing studies (5 acres or fewer) have examined the effects of livestock type (cattle, sheep, goats), grazing intensity (animals per acre) and grazing season (winter, early spring, late spring) on individual weed species (e.g., DiTomaso et al. 2007; DiTomaso et. al 2008; George et al. 1989, Lusk et al. 1961; Thomsen et al. 1993). These studies have consistently demonstrated that properly timed (late-spring, post-bolting/preflowering phenological stages - that is, immediately prior to seed head production) and intensive (high animal density resulting in high pressure on vegetation) grazing can reduce medusahead cover by $30 \%$ to $100 \%$ and yellow starthistle flower heads by $75 \%$ to $90 \%$ (DiTomaso et al. 2008; Thomsen et al. 1993). Experimentally manipulated livestock grazing has also been shown to enhance herbaceous diversity and native plant richness in vernal pools, interior annual grasslands and coastal grassland sites (DiTomaso et al. 2008; Hayes and Holl 2003; Marty et al. 2005). However, there is little published work examining pasture-scale (greater than 80 acres) implementation of prescribed grazing to manage invasive weeds.

\section{Pasture-scale prescribed grazing}

Across California, rangeland managers have reported that livestock grazing can be managed to control medusahead and yellow starthistle (Huntsinger et al. 2007).

Right, yellow starthistle (Centaurea solstitialis) flowers at full bloom and seed dispersal stages.

Below, medusahead (Taeniatherum caputmedusae) inflorescence with mature fruit.

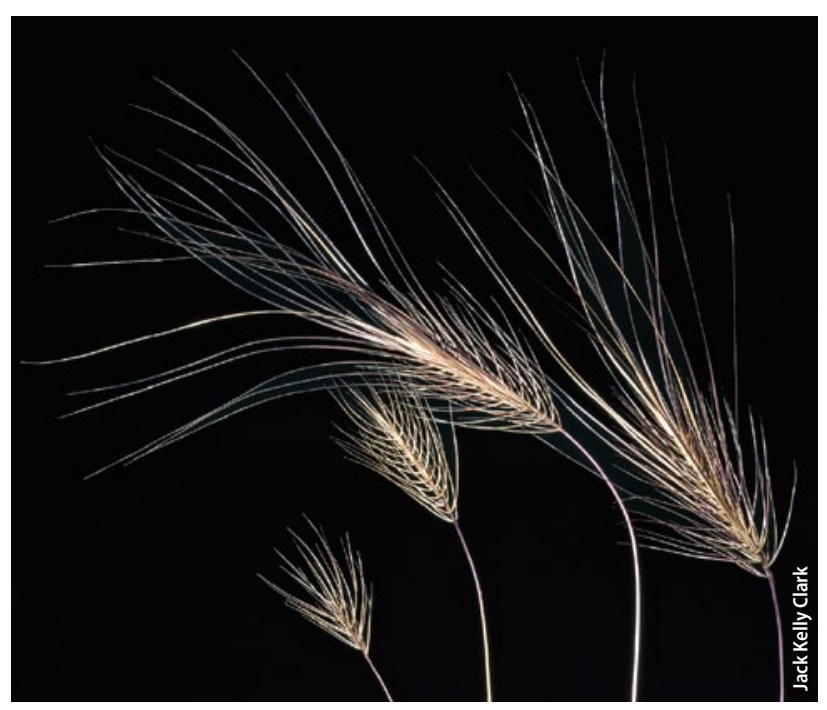

These findings are experiential rather than experimental - that is, based on direct implementation, observation and site-specific fine-tuning of intensity, season and frequency of livestock grazing to achieve specific goals. A recent scientific review of conservation effectiveness of rangeland management practices (including prescribed grazing) highlighted a critical need for the monitoring and reporting of practice effectiveness at the pasture scale (Briske et al. 2011). Collaborative, on-theground management implementation and monitoring will enable managers and researchers to better assess effectiveness and practicality of conservation practices such as prescribed grazing to control invasive weeds. Our objective was to assess the effect of a "real" prescribed grazing regime implemented by ranch personnel (rather than researchers) on medusahead and yellow starthistle populations on a Bureau of Land Management (BLM) grazing allotment known as the Bear Creek Unit of the Cache Creek Natural Area.

\section{Study site: Bear Creek Unit}

The Bear Creek Unit, located in Northern California's interior coast range in Colusa County, is an 11,090-acre (with 7,360 acres suitable for grazing) BLM-managed land that consists of a patch-mosaic of annual grasslands, blue oak woodlands and serpentine chaparral plant communities. The climate is 


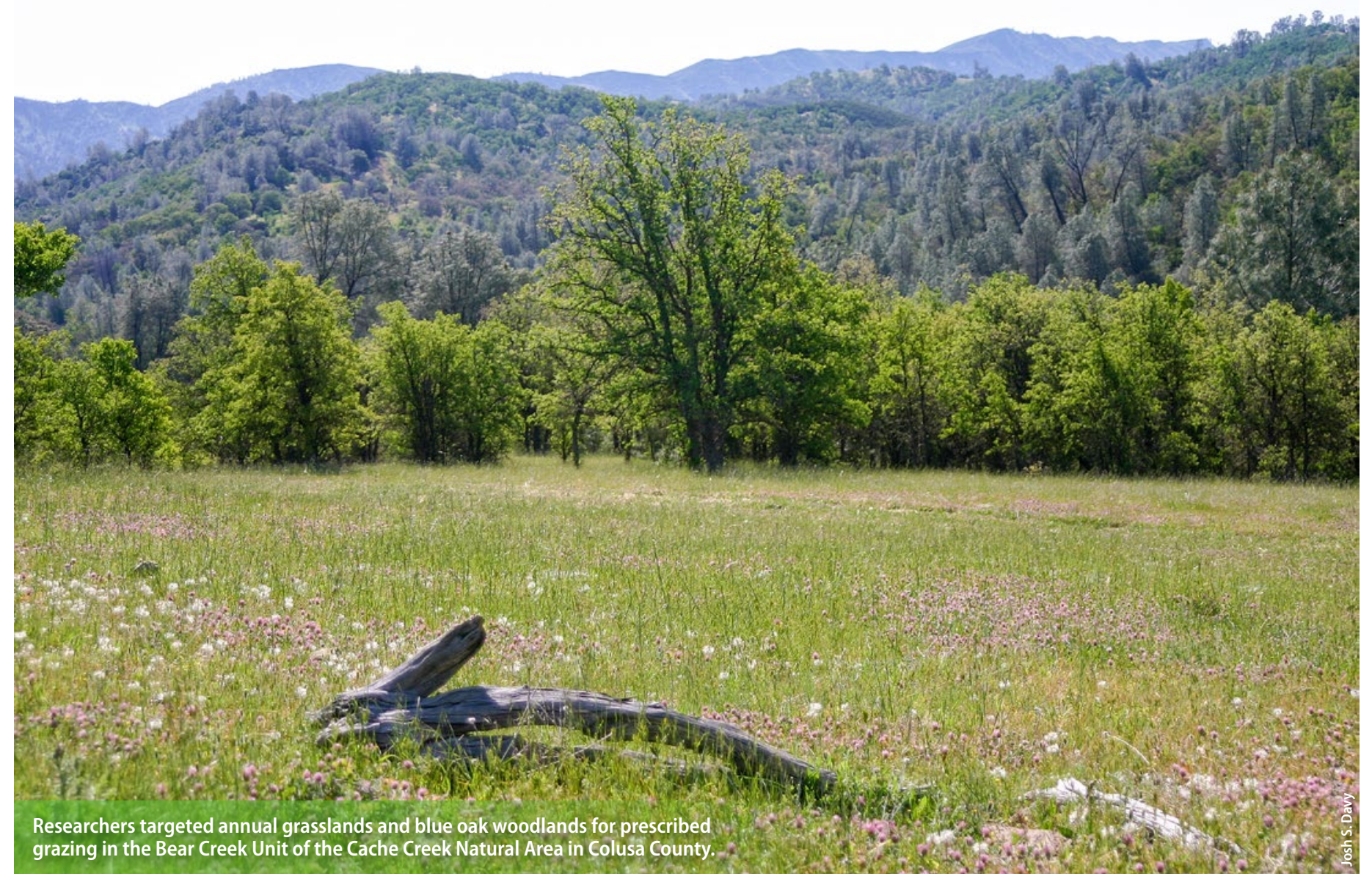

Mediterranean, with hot, dry summers and mild, wet winters. Mean annual precipitation is 24 inches, and mean annual air temperature is $61^{\circ} \mathrm{F}$ (PRISM 2011). Sites examined in this study ranged from approximately 1,200 to 1,600 feet in elevation.

For this study, we targeted the annual grassland and blue oak (Quercus douglasii Hook. \& Arn.) woodland plant communities, as they provided the majority of forage on the management unit, and were dominated by the target weeds. In the study area, soils were largely formed from residuum of sandstone and shale (Alfisols), with a small inclusion of soils formed from alluvium (Mollisols) (Soil Survey Staff 2012). Common nonnative annual grasses include soft chess (Bromus hordeaceus L.), slender oat (Avena barbata Link) and ripgut brome (B. diandrus Roth). This area also supports various native forbs, including miniature lupine (Lupinus bicolor Lindl.), Ithuriel's spear (Triteleia laxa Benth.), owl's clover (Castilleja attenuata (A. Gray) Chuang \& Heckard), mariposa lily (Calochortus spp.) and tidytips (Layia spp.). Native grasses are widely scattered in the area, with purple needlegrass (Stipa pulchra Hitchc.) being the most prominent native perennial grass. Medusahead and yellow starthistle are common across the landscape, with an emerging population of barb goatgrass (Aegilops triuncialis L.) also present.

\section{Grazing strategy}

Until August of 2001, the Bear Creek Unit was continuously grazed throughout the growing season under grazing leases. The BLM, which acquired the Bear Creek Unit in 1999, terminated grazing in 2001 in an attempt to enhance native plant cover. In the 4 years following cessation of grazing, BLM monitoring teams reported increased invasive weed cover and high accumulations and persistence of vegetative litter, or thatch (USDI 2004). In fall of 2006, average residual dry matter (RDM, the previous year's vegetative thatch) across the unit was estimated to be 4,200 pounds per acre. In working toward invasive weed control - one of BLM's top management priorities (USDI 2004; USDI 2011) - the BLM collaborated with local stakeholders to reintroduce grazing on the Bear Creek Unit in 2006.

To target medusahead and yellow starthistle, we implemented a moderately stocked, rotational cattle grazing system across 11 paddocks, ranging from 80 to 600 acres in size. Paddocks were generally grazed January through May using cows calving between January and March - cattle on and off dates, stocking densities and paddock rotations (table 1) were made at the discretion of the site manager based on factors such as drinking water availability, forage availability and cattle conditions (i.e., body condition score, weight gain). From 2006 to 2011, cattle numbers ranged from 318 to 520 , averaging 392 total cows during the study

TABLE 1. Late spring (May-Jun) and total (Oct. 1-Sep. 30, the water year) precipitation (ppt) as percent of average, and cattle grazing information for the sampling period 2006 to 2011

\begin{tabular}{|c|c|c|c|c|c|c|}
\hline & 2006 & 2007 & 2008 & 2009 & 2010 & 2011 \\
\hline $\begin{array}{l}\text { Late spring } \\
\% \text { of average ppt }\end{array}$ & 73 & 26 & 3 & 124 & 121 & 327 \\
\hline $\begin{array}{l}\text { Total } \\
\% \text { of average ppt }\end{array}$ & 156 & 40 & 55 & 52 & 81 & 92 \\
\hline Animal unit months* & 4,276 & 2,190 & 2,187 & 2,223 & 1,911 & 2,158 \\
\hline Cattle on-date & 7-Jan & 2-Jan & 16-Jan & 19-Nov & 19-Dec & 22-Nov \\
\hline Cattle off-date & 11-Jun & 27-May & 22-May & 23-May & 2-Jun & 25-May \\
\hline
\end{tabular}

* An animal unit month represents one cow grazed for one month. 
period. Grazing event duration ranged from several days up to 2 weeks, with two grazing events per paddock: one grazing from late November to February to reduce weed thatch, and allow alternative species to establish (George et al. 1989); and one grazing event from March to June to target late-flowering invasives (DiTomaso et al. 2008; Thomsen et al. 1993). By October of 2009, we estimated average RDM across the unit to be 1,400 pounds per acre, or approximately one-third the RDM observed under initial ungrazed conditions.

\section{Plant community analysis}

Prior to reintroduction of cattle grazing, we established permanent paired plots (one cattle grazed plot and one ungrazed exclosure; ITT 1996) in each of the 11 paddocks. Permanent plots were chosen in a random stratified manner to ensure sample sites were representative for each pasture. Exclosure plots measured 8 feet by 8 feet and were livestock proof. To examine shifts in plant species cover and abundance over the course of the study, we began monitoring plant community composition in June of 2006. At each set of permanent grazed and ungrazed paired plots, we estimated percent basal cover by species within a $10-\mathrm{ft}^{2}$ hoop. Ocular estimates of herbaceous composition (percent cover by species; ITT 1996) were collected after peak standing crop for both grazed and ungrazed plots in June of 2006, 2009 and 2011. This resulted in a total of 22 observations for each year, and 66 total observations for the study period.

To determine if grazing management at the Bear Creek Unit significantly impacted medusahead and yellow starthistle over the course of the study, we used linear mixed effects regression to examine trends in cover of these species between grazed and ungrazed treatments. The dependent variables observed were percent medusahead and yellow starthistle cover, and the independent variables were treatment (grazed, ungrazed), year $(2006,2009,2011)$ and the interaction between treatment and year. Within each treatment, we also examined changes in cover between the baseline (2006) and final (2011) evaluations for the most commonly occurring species: medusahead, yellow starthistle, soft chess, filaree (Erodium spp.), red brome (Bromus madritensis L.), ripgut brome, slender oat and a composite functional group composed of

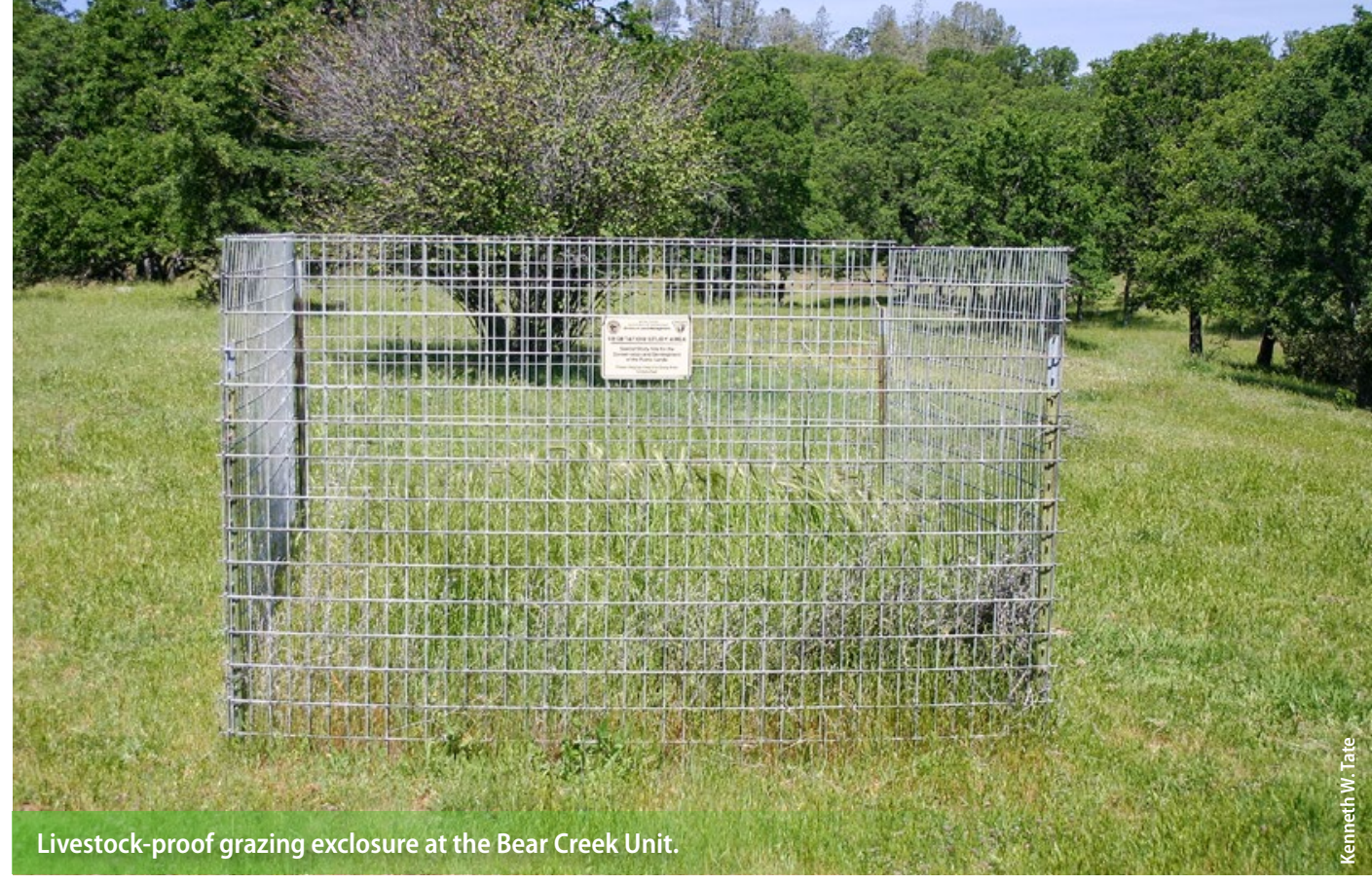

several thatch-loving species including red brome, ripgut brome and slender oat. We used linear and generalized linear mixed effects regression models to test for differences in percent observed species cover between 2006 and 2011. For all analyses, site identity was included as a random term to account for repeated measurements (Pinheiro and Bates 2000). Standard diagnostic tests were used to check assumptions of linearity, normality and constant variance. Analyses were performed using STATA/SE 13.0 statistical software (StataCorp 2013).

To examine changes in overall plant community composition, we used nonmetric multidimensional scaling (NMDS). NMDS is an ordination technique widely used to examine patterns in multidimensional data (e.g., plant community data) and, unlike other ordination methods, makes few assumptions about the data. Species cover values were log-transformed, and NMDS scores were calculated based on a Bray-Curtis dissimilarity matrix (McCune and Grace 2002). Analysis was conducted in the R software environment using the metaMDS routine from the vegan package (Oksanen et al. 2007; R Development Core Team 2010). The metaMDS function selects several random start positions to find a global solution, so that it does not become trapped at local optima. The final configuration is rotated via principal components so that the first dimension explains the greatest amount of variance. NMDS was run for 2 through 6 dimensions, with the optimal number of dimensions selected via examination of a scree plot, which displays stress versus dimensionality for each solution (McCune and Grace 2002).

To examine whether overall plant community composition significantly differed between grazed and ungrazed treatments, we used blocked (i.e., for paired plots) multiresponse permutation procedures (MRBP). MRBP provides a nonparametric test of multivariate differences between pre-defined groups, such as "grazed" and "ungrazed" plots (McCune and Grace 2002). Observations were blocked by plot pair identification number, and species cover data were log-transformed. MRBP was based on Euclidean distance measures and median alignment within blocks (McCune and Grace 2002).

\section{Yellow starthistle response}

Our analyses showed that prescribed grazing applied to Bear Creek Unit did not impact yellow starthistle cover. Trends in basal cover of yellow starthistle did not significantly differ between grazed and ungrazed treatments (fig. 1), with no significant changes in yellow starthistle cover for either treatment between baseline and final evaluations (fig. 2).

The lack of response to grazing may be due to a mismatch in the timing of grazing and the post-bolting/pre-flowering phenological stages of yellow starthistle. Since yellow starthistle matures and produces seeds later than other species, including medusahead, grazing late in the annual growing season (after May 1) is particularly important for effective suppression (DiTomaso at al. 2006). In addition, yellow starthistle populations commonly exhibit multiple life forms 


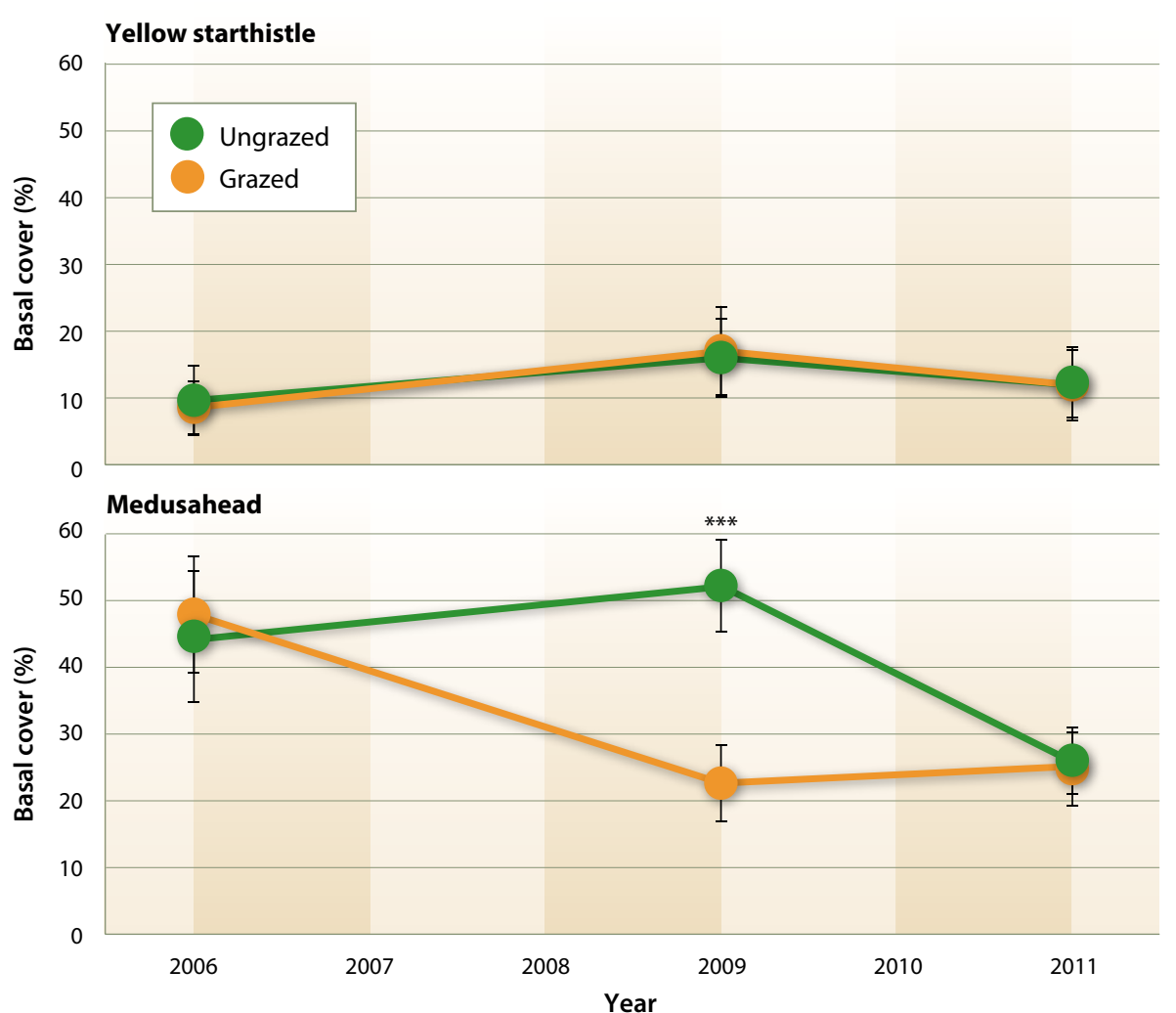

(A) Ungrazed

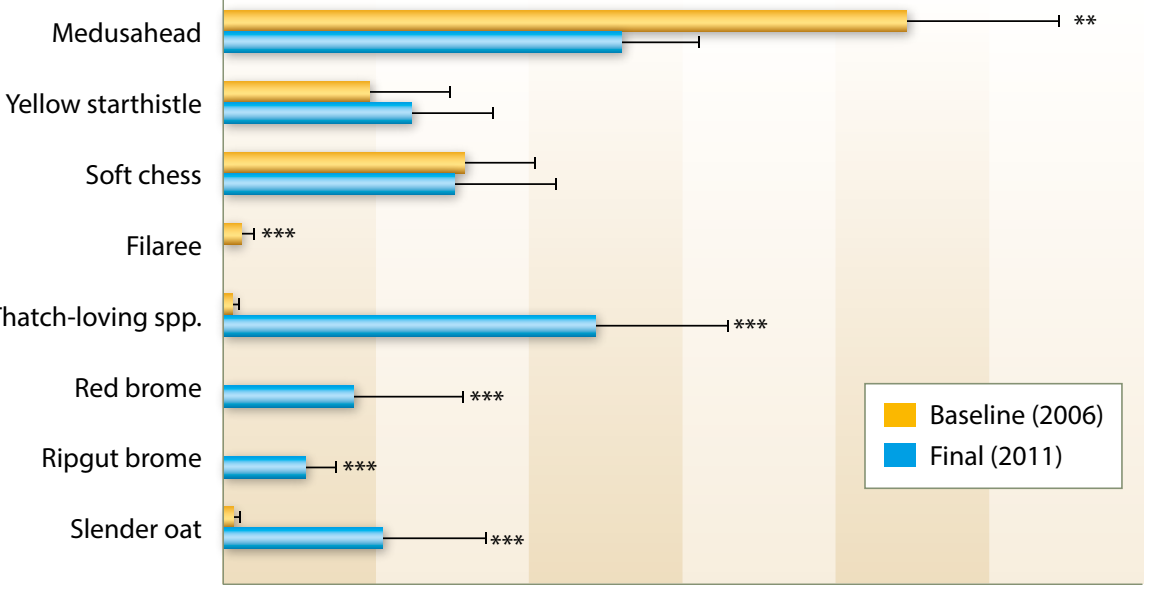

(B) Grazed

Medusahead

Yellow starthistle

Soft chess

Filaree

Thatch-loving spp.

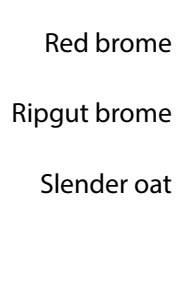

Fig 1. Change in percent basal cover of target herbaceous plant species from 2006 to 2011. *** indicates $P<0.01$.

(seedlings, rosettes, flowering adults, annual, biennial) simultaneously (DiTomaso 2000; Kyser et al. 2007). This diversity creates an additional obstacle to suppression, because individual plants are not all susceptible to grazing at the same time.

During this study, timing of cattle removal was dictated by real management considerations such as availability of water and desirable forage for livestock, which were both limited by May in most years. As a result, cattle were likely not present during the post-bolting/pre-flowering phenological stages when grazing can reduce yellow starthistle cover and seed production (DiTomaso et al. 2006; Thomsen et al. 1993).

\section{Medusahead response}

Following baseline (2006) botanical evaluations, medusahead cover within grazed treatment plots fell by roughly half in 2009. Additionally, in 2009, medusahead cover in the grazed treatment was significantly lower $(P<0.01)$ than that observed in the ungrazed treatment (fig. 1). However, by the final evaluation (2011), medusahead cover for both grazed and ungrazed treatments converged to similar levels.

As with yellow starthistle, research has shown that grazing late in the growing season (late April and May) is critical to successful medusahead control (DiTomaso et al. 2008). However, medusahead develops earlier in the spring than yellow starthistle and does not exhibit yellow starthistle's diversity of life forms. Medusahead's earlier maturing phenology narrows the window for grazing to achieve suppression. Although managerial constraints in this study made it impossible to graze late enough into the season to impact yellow starthistle, medusahead populations were impacted in several years. The differential reduction of medusahead cover in the grazed

Fig. 2. Changes in cover of the most commonly occurring species between baseline (2006) and final sampling events (2011) for ungrazed (A) and grazed (B) treatments. Cover values for thatch-loving species were calculated as the sum of ripgut, red brome and slender oat basal cover. ${ }^{*}$ indicates $P<0.1$; ${ }^{* *}$ indicates $P<0.05$; and ${ }^{* *}$ indicates $P<0.01$. 
thatch conditions (Amatangelo et al. 2008; George et al. 2001). Ripgut and red brome are also considered weedy invasives and provide little ecological or forage value (DiTomaso and Healy 2007). For the grazed treatment, there was a significant $(P<0.01)$ increase in filaree and slender oat, which are generally considered desirable forage species, and a significant $(P<$ 0.01 ) decline in ripgut and red brome (fig. 2B).

NMDS analysis confirmed divergence in overall plant community composition between grazed and ungrazed treatments during the study period. Initial plant community composition was not statistically different $(P=0.68)$ between grazed and ungrazed treatment plots in 2006 at the onset of grazing (fig. 3A). By 2009, plant communities significantly $(P<0.01)$ diverged between grazed and ungrazed treatments (fig. 3B), and remained significantly different in $2011(P<0.01)$ (fig. 3C).

\section{Management implications}

Annually adapting the timing of cattle removal based on seasonal rainfall patterns and phenology of target species may increase the effectiveness of grazing management to control invasive weeds such as medusahead and yellow starthistle. However, it is critical to acknowledge and address key management challenges, including availability and distribution of water and accessibility of sufficient cattle numbers for targeted grazing in late spring and early summer. This study of a prescribed grazing system demonstrates the continuing challenges and tradeoffs in balancing land management and conservation goals with the economic realities of livestock production, and highlights the need to cautiously translate small-scale research results into practical solutions for rangeland management. CA

J.S. Davy is UC ANR Cooperative Extension (UCCE) Livestock, Range and Natural Resources Advisor in Tehama, Glenn and Colusa counties; L.M. Roche is UCCE Rangeland Management Specialist in the Department of Plant Sciences at UC Davis; A.V. Robertson is Graduate Student at UC Davis; D.E. Nay is Range Specialist (retired), NRCS; and K.W. Tate is UCCE Rangeland Watershed Specialist in the Department of Plant Sciences at UC Davis.

\section{References}

Allen-Diaz B, Standiford R, Jackson RD. 2007. Oak woodlands and forests. In: Barbour MG, Keeler-WolfT, Schoenherr AA (eds.). Terrestrial Vegetation of California (3rd ed.). Berkeley, CA: UC Pr. p 313-38.

Amatangelo KL, Dukes JS, Field CB. 2008. Responses of a California annual grassland to litter manipulation. J Veg Sci 19:605-12.

Barrett RH. 1980. Mammals of California oak habitats-management implications. In: Plumb TR (ed.). Proceedings of the Symposium on the Ecology, Management, and Utilization of California Oaks. PSW-GTR-44. Berkeley, CA: USDA Forest Service. p 275-91.

Bartolome JW. 1987. California annual grassland and oak savannah. Rangelands 9(3):122-25.

Benefield CB, DiTomaso JM, Kyser GB, Tschohl A. 2001. Reproductive biology of yellow starthistle: maximizing late season control. Weed Sci 49:83-90.

Briske DD, Derner JD, Milchunas DG, Tate KW. 2011 An evidence-based assessment of prescribed grazing practices. In: Briske DD (ed.). Conservation Benefits of Rangeland Practices: Assessment, Recommendations, and Knowledge Gaps. Lawrence, KS: USDA Natural Resources Conservation Service. p 23-74.

Dahl BE, Tisdale EW. 1975. Environmental factors related to medusahead distribution. J Range Manag 28(6):463-68

D'Antonio CM, Malmstrom CA, Reynolds SA, Gerlach J. 2007. Ecology of invasive non-native species in Californi grasslands. In: Stromberg MR, Corbin JD, and D'Antonio CM. California Grasslands: Ecology and Management. Berkeley, CA: UC Pr. p 67-83.

DiTomaso JM. 2000. Invasive weeds in rangelands: Species, impacts, and management. Weed Sci 48(2):255-65. DiTomaso JM, Healy EA. 2007. Weeds of California and Other Western States. Oakland, CA: UC ANR.

DiTomaso JM, Kyser GB, George MR, et al. 2008. Control of medusahead (Taeniatherum caput-medusae) using timely sheep grazing. Invas Plant Sci Manage 1(3):241-47.

DiTomaso JM, Kyser GB, Pitcairn MJ. 2006. Yellow Starthistle Management Guide. Berkeley, CA: California Invasive Plant Council.

Eviner VT, Hoskinson SA, Hawkes CV. 2010. Ecosystem impacts of exotic plants can feed back to increase invasion in western US Rangelands. Rangelands 32(1):21-31.
Garrison B, Standiford RB. 1996. Oaks and habitats of the hardwood rangeland. In: Standiford RB, Tinnin P, Adams T. Guidelines for Managing California's Hardwood Rangelands. Oakland, CA: UC ANR. p 8-17.

George MR. 1992. Ecology and management of medusahead. UC Range Science Report 23:1-3.

George M, Bartolome J, McDougald N, et al. 2001. Annual Range Forage Production. UC ANR Pub 8018. Oakland, CA. $p 6$

George M, Knight R, Sands P, Demment M. 1989. In tensive grazing increases beef production. Calif Agr 43(5):16-9. doi:10.3733/ca.v043n05p16

Hayes GF, Holl KD. 2003. Cattle grazing impacts on annual forbs and vegetation composition of mesic grasslands in California. Cons Bio 17(6):1694-1702.

Hironaka M. 1961. The relative rate of root development of cheatgrass and medusahead. J Range Manage 14(5):263-67.

Huntsinger L, Bartolome JW, D'Antonio CM. 2007. Grazing management on California's Mediterranean grasslands. In: Stromberg BE, Corbin JD, and D'Antonio CM (eds.). California Grasslands: Ecology and Management. Berkeley, CA: UC Pr. p 233-53.

[ITT] Interagency Technical Team. 1996. Sampling vegetation attributes, Report BLM/RS/ST-96/002. Denver, CO: US Department of the Interior, Bureau of Land Management-National Applied Resources Science Center. Kyser GB, DiTomaso JM, Doran MP, et al. 2007. Control of medusahead (Taeniatherum caput-medusae) and other annual grasses with imazapic. Weed Technol 21(1):66-75 Lusk WC, Jones MB, Torrell PJ, McKell CM. 1961. Medusahead palatability. J Range Manage 14:248-51.

Maddox DM. 1981. Introduction, phenology, and density of yellow starthistle in coastal, intercoastal, and central valley situations in California. Albany, CA: USDA Agricultural Research Service.

Major J, McKell CM, Berry LJ. 1960. Improvement of Medusahead Infested Rangeland. Berkeley, CA: California Agricultural Experiment Station Extension Service.

Marty JT, Collinge SK, and Rice KJ. 2005. Responses of a remnant California native bunchgrass population to grazing, burning and climatic variation. Plant Ecol 181(1):101-12.

McCune B, Grace JB. 2002. Analysis of Ecological Commu nities. Gleneden Beach, Oregon: MjM Software.
Oksanen, J, Kindt R, Legendre P, et al. 2007. The Vegan Package. Version 1.17-7.

Olson BE, Lacey JR. 1994. Sheep: a method for controlling rangeland weeds. Sheep Res J (Special Issue):105-12.

Pinheiro JC, Bates DM. 2000. Mixed-Effects Models in S and S-PLUS. New York, NY: Springer-Verlag.

Pitcairn MJ, O'Connell RA, Gendron JM. 1998. Yellow starthistle: Survey of statewide distribution. In: Woods DM (ed.). Biological Control Program Annual Summary, 1997. Sacramento, CA: CDFA, Plant Health and Pest Prevention Services. p 64-6.

PRISM. 2011. PRISM Climate Group. prism.oregonstate. edu.

R Development Core Team. 2010. R: A Language and Environment for Statistical Computing. Vienna, Austria: R Foundation for Statistical Computing.

Schiffman PM. 2007. Species composition at the time of first European settlement. In: Stromberg BE, Corbin J, D'Antonio CM. California Grasslands: Ecology and Management. Berkeley, CA: UC Pr. p 52-6.

Sheley RL, Jacobs JS, Martin JM. 2004. Integrating 2,4-D and sheep grazing to rehabilitate spotted knapweed infestations. J Range Manage 57:371-75.

Soil Survey Staff. 2012. Web Soil Survey. websoilsurvey. nrcs.usda.gov. USDA Natural Resources Conservation Service. Accessed April 21, 2012

StataCorp. 2013. Stata Statistical Software: Release 13. College Station, TX: StataCorp LP.

Thomsen CD, Williams WA, Vayssieres MP, et al. 1993. Controlled grazing on annual grassland decreases yellow starthistle. Calif Agr 47(6):36-40

[USDI] US Department of the Interior. 2004. Cache Creek Coordinated Resource Management Plan. Ukiah, CA: USDI Bureau of Land Management. p 120

USDI. 2011. Invasive \& noxious weeds (invasive species). Washington D.C.: Bureau of Land Management. blm. gov/wo/st/en/prog/more/weeds.html (accessed June 19, 2012)

Young JA. 1992. Ecology and management of medusahead (Taeniatherum caput-medusae). Great Basin Nat 52(3):245-52.

Young JA, Evans RA, Kay BL. 1970. Phenology of reproduction of medusahead. Weed Sci 18(4):451-54. 